\title{
From Dreams to Disillusionment: A Socio-Cultural History of the American Space Program
}

\begin{abstract}
This article offers an insight into the history of the U.S. space program, including its cultural and political aspects. Starting from the vision of space as a new field of peaceful and exciting exploration, predominant in the first half of the $20^{\text {th }}$ century, moving through the period of the intensive and eventually fruitful Cold War competition between the two belligerent ideological blocs led by the United States and the Soviet Union, and ending with the present-day cooling of the space enthusiasm, it focuses on the main actors and events of the century-long struggle for reaching the stars. The article is based in part on primary journalistic sources in order to capture the social atmosphere of the times it focuses on. It points out to the mid-1960s as the time when the noble aspirations and optimism of the early cosmic endeavors started to succumb to the pressure of reality, which caused the overwhelming stagnation of space initiatives, effectively ending the Golden Age of extraterrestrial exploration. This argument is backed by an analysis of historical developments leading to and following the American conquest of the Moon.
\end{abstract}

Key words: space, astronautics, history, U.S., Cold War

\section{Introduction}

In the $17^{\text {th }}$ century, Italian scientist Galileo used a new instrument that enabled him to see new clarity in the objects in the night sky. The public now learned of the remarkable craters and mountains on the surface of the moon. It was soon confirmed that several planets in the solar system circled the Sun in a predictable manner. These discoveries occurred at a time when European explorers were mapping out the strange new lands they called the "New World." A number of thinkers began to view these distant planets as the next frontier to be explored. The only limit was the technology to get there - and whatever lay beyond our own planet was limited only by the human imagination. And there was a popular belief that the Moon was indeed a strange world harboring strange civilizations. 
In 1835, the New York Sun fooled a generation of Americans with a widely publicized hoax. Its articles told the story of an astronomer using a powerful new telescope to view a fantastic and lush civilization on the Moon inhabited by "bat-like winged humanoids." In 1865, Jules Verne referenced this "Great Moon Hoax" in his book From the Earth to the Moon. That story told of a group of Civil War weapons manufacturers that used a powerful cannon to propel a team of explorers to the surface of the Moon. The science was dubious - but the notion was introduced that one day an average citizen might enjoy the experience of visiting the neighboring planets.

The space travel intrigued Americans at a time when Frederick Jackson Turner wrote of the significance of the closing of the Western frontier. If that were so the space seemed the last frontier to search for adventure.

Those questions also seemed to be taken seriously by the best scientific minds of the era. In 1895, astronomer Percival Lowell famously postulated that Mars was an arid landscape with an advanced civilization constructing a complex series of canals to transport water from the polar caps. In 1911, Edgar Rice Burroughs began his popular series "Princess of Mars" that told of the Civil War veteran John Carter engaged in dramatic sword battles on the planet Mars.

The series would influence a generation of science fiction writers and give rise to a new brand of American hero. American radio listeners were entertained by the outer space adventures of Flash Gordon - the fearless space explorer dashing throughout the solar system. The idea that Mars was populated was almost conventional wisdom. In 1938, millions of Americans were terrified by a dramatic reading of War of the Worlds depicting giant Martian invaders landing in New Jersey and destroying the Earth with massive death rays (McQuail 477). The drama was so convincing that thousands of Americans took to the highway in an attempt to escape the Martian invasion force.

But this would only stimulate interest in the grand questions regarding outer space. At the 1939 New York World's Fair, thousands lined up to pay 25 cents to take a "ride" in a giant vibrating steel tube said to simulate a rocket trip to Venus that was advertised as a "jungle planet" inhabited by dinosaurs.

That was of course simply an educated guess. But the lack of hard science only added to the popular curiosity: and the questions seemed endless. What was on those planets? Would humans one day live comfortably on the surface of the Moon? Was there a civilization on Mars supported by an elaborate system of canals? All that was needed, it was suggested, was the technology to reach these strange new worlds. And that technology would come sooner than almost anybody expected.

\section{The V-2 and Moral Dilemmas of Science}

In 1928, Wehrner Von Braun was among many young Germans fascinated by the Fritz Lang film Woman on the Moon. This was regarded as the first real "hard science fiction" film that presciently foreshadowed the coming era of modern space travel. The rocket technology seen in the film was said to be so precise and realistic that in the 1930s, Nazi Germany banned the film in order to protect its top secret rocket program then in development along on the Baltic Sea port of Peenemunde. 
In World War II, Von Braun and a team of engineers perfected the V-2 rocket system. This was in essence the world's first "space ship" - a pilotless guided ballistic missile capable of carrying its own fuel and oxygen high into the stratosphere before landing to inflict mass devastation on its targets in England and Belgium.

As the war came to a close, both the Soviet and American armies hoped to capture the team responsible for this mysterious new rocket technology. In early 1945, the United States military captured Von Braun and under the top-secret program "Operation Paperclip" the Americans transported Von Braun and 120 of his rocket engineers to a military outpost in Fort Bliss, Texas. Over a period of several months, Von Braun painstakingly outlined the details of the V-2 technology. This included the chilling claim that the V-2 team had almost completed a massive 100-ton rocket capable of flying over the Atlantic Ocean to strike the largest cities in the United States ("Nazis Planned Rocket to Hit U.S." 34).

At a time Nazi war criminals were standing trial in Nuremburg the presence of the German rocket team in the United States raised some troubling moral questions. It was known that Von Braun was a former high-ranking member of the Nazi Party and the V-2 weapon systems had been manufactured in horrific labor conditions. For the next three decades American officials would accept Von Braun's claim that he was an apolitical man of science and his work with the Nazi military was an unfortunate necessity of working under a totalitarian regime. Von Braun was occasionally reminded about his Nazi past in public appearances. A later film on his life was entitled I Aim for the Stars led some to add the sardonic retort "but I sometimes hit London" (Murray, and Cox 36).

But the cold reality was that the United States was embroiled in the cold war struggle with the Soviet Union. And both sides in that war saw this new rocket technology as a matter of national survival. In the age of the atomic bomb both sides knew they were more vulnerable than ever before. And this was reflected in what became a new theme in science fiction. The world was now capable of destroying itself - and there might one day be a necessity to colonize another planet. In 1950 novelist Ray Bradbury published The Martian Chronicles that told the grim story of Earthlings fleeing a planet devastated by an atomic war and what transpires when the Earthlings encounter the Martian natives.

In the 1950s von Braun became a leading voice advocating the need for space exploration. The United States, he insisted, must explore space for the same reason the great European explorers once left the confines of the Mediterranean Sea in search of a New World. But this analogy implied that "somebody" would be out there that would one day be "discovered." But were they out there? In the 1950s Americans seemed more than willing to entertain that idea in popular films with colorful titles like The Forbidden Planet, Radar Men from the Moon, Zombies from the Stratosphere, Abbott and Costello Go To Mars, and I Married a Monster from Outer Space.

Von Braun took a more serious tone and insisted that exploring the nearby planets should be compared to the days of the $19^{\text {th }}$ century when the great powers competed for the mastery of the seas. This nascent rocket technology would one day make the planets accessible to hostile nations - and there was reason to believe that by the late $20^{\text {th }}$ century the Soviet Union would have the technology to colonize the planets of the solar system perhaps as easily as they had occupied Eastern Europe. He stimulated the popular imagination in an article in Collier's magazine entitled 
"Man Will Conquer Space Soon" that predicted several manned artificial satellites would permanently circle the earth and be used for astronomical and weather observation and also serve as the most potent guardian of international peace as well as be jumping boards for ventures into deep space. The article drew more attention with its dramatic color illustrations depicting complex satellite stations floating elegantly above the planet Earth. "It would admittedly be expensive" Von Braun conceded "although the expense would be small compared to current armament budgets" ("Scientist Projects Journey to Mars" 30).

October of 1953 marked the $50^{\text {th }}$ anniversary of the maiden flight of the Wright Brothers. The New York Times marked the occasion with an article entitled "A Bold Look at the New Fifty Years of Flight." Von Braun offered the rather conservative views. "By 2003," von Braun concluded, "man will have set foot on the moon and plans will be under serious consideration for the exploration of the nearer planets" ("A Bold Look..."). He would actually put these words into action by eventually preparing a detailed plan for the future exploration of Mars (Bignami, and Sommariva 9-12).

In hindsight those rather conservative predictions would be accelerated by a dramatic event that in the coming decade would push those dates dramatically forward. In October of 1957 the Soviet Union launched the first artificial satellite. Sputnik was a 184-pound metal sphere that circled the earth every 90 minutes emitting a beeping sound heard around the world. The military and political symbolism was immense - and it was clear the Soviet Union was exceeding the United States in terms of science and technology. And the stake could not be higher. Edward Teller warned: "If they surpass us in technology in the years immediately ahead there is very little doubt who will determine the future of the world" (Newsweek, November 11, 1957). And so it happened that "over the next decade, the two superpowers of the planet, the governments of the United States of America and the Union of Soviet Socialist Republics, would compete with each other to be the first to exhibit increasingly impressive, complex, and costly abilities in space in what became popularly known as the space race" (McDonald 160).

\section{The Space Race}

In January of 1958 Von Braun would counter Sputnik with the launch of satellite Explorer II. President Eisenhower followed this up with the founding of the government agency National Aeronautics and Space Administration (NASA). The United States and the Soviet Union were now locked in the "space race" but still it was the USSR that seemed to be extending its lead in this competition.

In January of 1961 President John Kennedy came into office wanting to change that equation. The dynamic young president personified the confidence of a new decade. He brought the "brightest and the best" into the White House who were convinced that there was nothing that could not be accomplished.

In April of 1961, Soviet cosmonaut Yuri Gagarin became the first human to orbit the Earth. Kennedy's advisers suggested him to consider a larger goal. On May 25, 1961 John F. Kennedy gave his pledge before the American Congress: "I believe that this nation should commit itself to achieving the goal, before this decade is out, of 
landing a man on the Moon and returning him safely to the Earth" (Special Message to the Congress...).

Was this possible? Nobody could say for sure. And that challenge was part of the drama that over the next decade would capture the popular imagination. Kennedy stressed the emotional aspect of that challenge in a speech at Rice University in 1962. "We choose to go to the Moon! (...) We choose to go to the Moon in this decade and do the other things, not because they are easy, but because they are hard..." (Address at Rice University...).

Kennedy pledge would attempt to harness the energy of a remarkable scientific and technological revolution that seemed capable of almost anything imaginable and over time would also shape a better future for all Americans.

The space race had captured the imagination of an entire culture. While unmanned space vehicles might have served science better a than manned flight to the moon, the astronauts were part of the glamour of the challenge of exploring the new mysteries of space.

Space historian Thomas A. Heppenheimer wrote that the American astronauts were designed to give a human face to the U.S. space effort, and to raise hopes for the broader American society (192-193). In turn the American public was fascinated with its new team of daring "Mercury 7" astronauts (Koppel 21-22). They were dressed in silver suits that intentionally harkened back to the images of Flash Gordon and paraded before the admiring media like Hollywood stars blazing the same heroic trail as Columbus and Daniel Boone had in previous generations.

In the early 1960s, American cars began to resemble the sleek space ships and the average home fashion was decorated with colorful plastic and aluminum furniture to give American homes the fashionable look of the "space age." On television Americans were entertained by "The Jetsons" which transplanted an average suburban family into the space age. Across the country children drank the previously obscure "Tang" instant breakfast drink simply because John Glenn was said to have enjoyed the drink on his historic orbital flight. Even the American skyline reflected the fascination with space. In Seattle, the futuristic Space Needle towered above the 1962 World's Fair. In the "space city" of Houston construction began on a symmetrical indoor sports stadium called "The Astrodome" that its engineers modestly called the "Eighth Wonder of the World."

The shock of Sputnik had called into question the efficacy of the American socioeconomic system (Dickson 140). Kennedy's vow to land a man on the moon was said to have unleashed the collective power of the entire American economy. NASA would employ 30,000 scientists and technicians. The federal government devoted unprecedented funds into scientific research and development carried out in the laboratories of universities and independent research institutes. And the results would benefit not only the space program - but the average consumer. The Teflon coating invented for rocket exhaust nozzles could also keep burned eggs from sticking to the frying pan. Even the powerful aerosol hair sprays that held Jackie Kennedy's fashionable bouffant hairstyle in place were said to be a technological "spin-off" of the race for the space program. Even if those stories were only partially true the facts mattered less than the perception that the space research was benefitting the entire culture (Hodgson 6). 


\section{The End of Optimism}

The unbridled mood of American confidence came to an end in November of 1963. The assassination of John Kennedy stunned the nation. The dynamic young president was now seen as a martyr cut down in his prime - perhaps even by those that did not share his grand vision of reaching for the stars. Indeed Kennedy's successor Lyndon Johnson vowed to follow the "ideas and ideals" which Kennedy had "so nobly represented." This would include the continuation of the stated goal of reaching the moon by the end of the decade.

But that lofty goal threatened to be overshadowed by problems closer to home. 1964 President Johnson called on America to build a "Great Society" that "rests on abundance and liberty for all." The "war on poverty" would begin to cut into the space budget with a focus on ending poverty and devoting greater resources to improve health, education, and housing.

By 1965 more liberal minded officials began to ask the grand question that began to challenge the logic of spending vast sums to place a man on the moon. How could the government spend so much money on space when there were so many problems closer to home? In New York City, Mayor John Lindsay spoke for many liberals asking for more money to be allocated from the space program to the troubles of the American city. "I would not want the U.S. to be described by future generations as a society that stood amidst the filth, the oppression and the violence of its slums and shot rockets to the Moon" ("Why Should Man Go To the Moon?"). NASA supporters, in turn, argued that space research had led to several technological breakthroughs and these budget cuts risked putting an end to "the most scientifically productive decade in the history of our culture" (Clark 6).

At the same time advances in technology were removing some of the mystery that had stoked so much interest in the early half of the $20^{\text {th }}$ century. In July of 1965, NASA released its first series of dramatic photographs of Mars taken from the probe Mariner 4 displayed a bleak and barren crater pocked and landscape. This was seen as the "fatal blow" to any lingering hopes of an advanced civilization even having inhabited the red planet. That news also brought relief to a generation sent into panic by a radio drama of a Martian invasion. "As a member of a generation that Orson Welles scared out of its wits," President Johnson told NASA officials "I must confess that I am a little bit relieved that your photographs didn't show more signs of life out there" (Sullivan 1).

And the other neighboring planet seemed even less promising. In 1967, the Mariner 5 probe showed that Venus was hardly the jungle planet imagined in the early days of the $20^{\text {th }}$ century. In reality it was now clear the surface of Venus was an inhospitable inferno with furnace like temperatures that one physicist described rather bluntly as a "hellhole" (Wilford, "Venus is Found to Be a 'Hellhole'..." 17).

The grand idea of space exploration was retained in the popular culture. If the neighboring planets were barren and uninhabitable the writers might simply extend their stories deeper into space. This idea was seen in the popular television show Star Trek that followed the swashbuckling Captain James T. Kirk leading a multinational crew in what was boldly proclaimed as the "final frontier" as easily as explorers had once sailed the Seven Seas. And that premise added to the enthusiasm as Apollo 11 prepared to make history in the summer of 1969. 


\section{Apollo 11: One Giant Leap for Mankind}

In July of 1969, millions of spectators began to gather in the distance before the Saturn V rocket that would carry the Apollo 11 team of three astronauts 240,000 miles into space to become the first humans ever to walk on the surface of the Moon. A million spectators were eventually joined by politicians, celebrities, and a thousand journalists representing some fifty countries from around the world.

On July 20, 1969 the world watched as Neil Armstrong placed his foot on the gray and powdery surface of the Moon. "That's one small step for man," he said in what became immortal words, "One giant leap for mankind" (Kranz 305). The magnitude of the event was hard to overstate. Nixon did his best in suggesting that the Moon landing was probably "the greatest week since the Creation."

NASA officials took efforts to portray the moon landing as only the first step in a new glorious age of space exploration. It had become almost conventional wisdom that by the 1990s average citizens would be vacationing comfortably in domed communities on the Moon. This would be as simple as a vacation in the Arizona desert, as one NASA official explained with marked confidence: "It will be like Phoenix. Brilliant sun and stars, dramatic landscapes, mountains and craters, a magnificent view of the Earth" (Buckley 100).

This optimism was not limited to American space officials. The Hilton hotel chain announced early plans to construct a hotel on the surface of the Moon. Pan Am and TWA airlines began accepting reservations for the first commercial flights to the Moon. California Governor Ronald Reagan was among the first to sign up for this grand new adventure of affordable space travel.

These grand projections would in later years prove rather optimistic. A growing number of critics insisted the space projects outlined in the halcyon days of the early 1960s were no longer affordable. By 1970, the American economic prosperity had stalled to a halt. Inflation coupled with recession and mounting unemployment led to a new decade of pessimism. The economy had been stalled by spiraling inflation that was partially the result of the refusal to raise taxes to pay for the Vietnam war. The largest cities faced bankruptcy and the public was more concerned about increasing unemployment and soaring energy prices. At the same time President Nixon was establishing a new and more cooperative relationship with the Soviet Union. If this was true why was it still necessary to compete with the Soviet Union in space?

NASA was thus faced with the troubling question of what they could possibly do for an encore. The space project had cost an estimated $\$ 150$ billion. A growing number of critics began to ask what would be gained by landing another expensive spacecraft on a lifeless gray rock floating in the midst of a cold universe? A few short months later, the drama of the Apollo 11 mission had already begun to fade. In the autumn of 1969 the team of Apollo 12 astronauts visited the White House. They were surprised when President Nixon seemed more willing to discuss an upcoming college football game than their upcoming return trip to the Moon ("The Future of NASA").

The money (and the public interest) was no longer there. The original plans called for ten Moon landings - from Apollo 11 through 20. The Nixon White House announced the cancelation of the final three lunar missions due to lack of adequate 
funding. The final moon walk in December of 1972 seemed anticlimactic to a public that seemed to lost their fascination with televised images of astronauts walking on the surface of the moon. "Let's get this mother out of here," said astronaut Eugene A. Cernan as he lifted the final shuttle craft from surface of the Moon. But few would remember his name or his words that were in marked contrast to Neal Armstrong's stirring phrase commemorating a "giant leap for mankind" only three and a half years earlier.

\section{End of the dream}

In January of 1970, NASA announced a series of budget cuts. The once celebrated teams of technicians and engineers were dismantled and the districts around the Florida launch site began to resemble high tech ghost towns.

Wernher Von Braun and the original German rocket team hoped to spend 1970 commemorating the $25^{\text {th }}$ anniversary of their arrival in the United States. Instead many of them let go as part of the cuts in the space budget (Lyons 1). In 1972, Von Braun left NASA for a position at a private aerospace company. He insisted he was leaving with the knowledge that NASA would continue its "well thought out plans" even if "some of these many have to be deferred because of budget constraints" (Schmeck 1, 43).

Von Braun left the space program insisting that the United States must continue to study the feasibility of one day reaching distant reaches of the universe. Why? Just because logic held that human beings would invariably have to colonize distant planets simply in order to survive as a species (Wolfe). And that project must be an ongoing process and it must begin as soon as possible. But this was a difficult case to make in an era marked by a significant economic downtown.

There was also a disheartening question that called into question the idealistic visions of the early $20^{\text {th }}$ century. Was our universe simply too vast for human beings to ever realistically explore? In 1972, NASA launched Pioneer 10 with the mission to photograph Jupiter. Some years later the probe sped out of the solar system traveling faster than any previous man-made object. But even at those remarkable speeds it would take an estimated 100,000 years for the object to reach the nearest star. All of that suggested the drama of Flash Gordon and Star Trek seemed increasingly like naïve scenarios written by those unaware of the vast distances that separated our own planet from the nearest star systems (Whitfield 18-20).

By the mid-1970s a generation jaded by the war in Vietnam and the Watergate crisis began to ask even more troubling questions. What if it all never happened? A few months after Apollo 11 The New York Times ran a short feature article entitled "Moon Landing? What Moon Landing?" The writer described a recent conference of the "Man Will Never Fly Memorial Society." At the meeting a NASA employee showed a film that appeared to be the surface of the Moon. He then revealed the footage had been taken from an ordinary rock quarry in Michigan. The NASA official said the purpose of the film "is to indicate that you can really fake things on the ground - almost to the point of deception... You can come to your own decision about whether or not man actually did walk on the Moon" (Wilford, "Moon Landing? What Moon Landing?" 30). 
And there was an element on the fringe of American opinion that decided that may have been true. In the mid-1970, eccentric writer Bill Kaysing gained a degree of attention with his self-published book entitled "We Never Went to the Moon: America's Thirty Billion Dollar Swindle." This was followed a few years later by a blockbuster feature film Capricorn One which dramatized a secret government plot to fake a proposed trip to Mars from a film studio. Though this was still a fringe element the idea would grow over time that the Apollo program had been based on an elaborate hoax.

In 1977 Jimmy Carter came to the White House preoccupied with problems closer to home. The American economy was mired in a recession and there was little serious talk about a return to the Moon. The previous proposals of travelling to Mars by the 1980s now seemed out of the question. "It is neither feasible nor necessary at this time to commit the United States to a high-challenge space engineering initiative comparable to Apollo," read a curt response from the White House to mark NASA's $20^{\text {th }}$ anniversary.

NASA officials had initially placed their hopes in "Skylab," the $\$ 2.6$ billion spacestation that had been widely hailed as the great follow-up to the Apollo project. In July of 1979 , the space program should have been celebrating the $10^{\text {th }}$ anniversary of the historic Moon Landing. Instead it had the dubious task of announcing that its 77-ton space station would soon come crashing into Earth. It took a last minute maneuver to guide the floundering space station away from the heavily populated areas of North America before it crashed into the Indian Ocean and the lightly populated Australian outback. President Carter was compelled to send the Australians an apology after a NASA official said that it was lucky the shuttle came down in Australia because "there were only kangaroos there" ("Several Chunks Are Found" 7).

But the symbol of the billion dollar space station crashing to the Earth seemed a fitting metaphor for the gloomy decade of the 1970s. And more citizens sought an escape with a return to the more innocent days of science fiction. Movie director George Lucas sought to make an update of the old Flash Gordon films. Instead he made the film Star Wars which broke box office records with an optimistic story that harkened back to the science fiction pulp fantasies of the early $20^{\text {th }}$ century.

President Ronald Reagan came to the White House in 1981 stressing a new vision of optimism. The American economy rebounded strongly and it was suggested that this was due in part to several "spin offs" associated with space program including the advancements in computer technology. NASA turned its focus to the much publicized "Space Shuttle" that would theoretically be able to fly into deep space before returning to Earth and landing softly like a conventional airplane (Godwin 3-4). After some early promise the space shuttle was proving a costly boondoggle even before the shuttle Challenger exploded in midair in January of 1986.

The most debated questions regarding space were found in the Strategic Defense Initiative (SDI) which would use floating satellites as a shield against incoming nuclear weapons. But even that question faded when the Soviet Union began to collapse in the course of the 1980s. The demise of the Soviet Union led American film makers to search for new villains. And in many cases that villain turned out to be their own government. The cynicism of the early 1990s was seen in the popular TV show called The X-Files that was premised on an elaborate government conspiracy to hide the fact that extraterrestrials had landed in the late 1940s. This atmosphere 
of skepticism was perhaps responsible for the surprise underground success of the documentary film A Funny Thing Happened on the Way to the Moon (2001) that again claimed the Moon landings were a hoax staged for the sake of Cold War propaganda.

It was already in the 1960s that astronomers associated with the Search for Extraterrestrial Intelligence (SETI) began targeting a massive bank of radio telescopes at the sky. The stated goal was to receive signals from a distant civilization. All they had to do, officials insisted, was to listen and wait for the proverbial "little green men" to return their call. But when would that be?

In 1980 Dr. Carl Sagan became a national celebrity hosting the television series "Cosmos." As a young man Sagan had grown reading Edgar Rice Burroughs A Princess of Mars. The idea of one day making contact with alien life became a lifetime obsession. Sagan confidently assured that the universe held hundreds of millions of galaxies. In each episode he would assure his viewers that the sheer mathematical odds made it almost impossible not to believe in extraterrestrial life. Again, it was assured that all we had to do was wait and that day of "contact" would come. And conventional science suggested that he was probably right. But would if he was not?

There were some that said that may not ever occur. In the 1950s, physicist Enrico Fermi was discussing the wave of popular UFO sightings. If the popular culture saw this as firm proof the planet was being visited by "flying saucers." Fermi did the rough math on the probability of Earth-like planets existing in the universe. He concluded that if there were so many we should have been visited by now. That became known as the "Fermi Paradox." If there were so alien civilizations out there, why was there no evidence of their existence? Some began to offer an answer that would challenge the ideas that had dominated the popular imagination since Galileo had first viewed the surface of the Moon through his rudimentary telescope.

By the $21^{\text {st }}$ century some scientists began to consider a controversial idea known as the "Rare Earth" theory that challenged the ideas of ever finding intelligent life in the universe. The real reason that we have not yet seen any aliens is that conditions within the universe might simply be too hostile to sustain intelligent life. Despite Sagan's optimistic postulations of one day finding life among billions of galaxies it was also conceivable that the conditions for life on Earth (liquid water, mild temperatures, and protection from lethal radiation) might be exceedingly rare (Golden). The complex elements of our planet may in fact be extraordinarily rare.

As the world entered the $21^{\text {st }}$ century there was a lingering question that challenged almost every premise of the space age. Most importantly - would if we were all "alone" - and the hopes and dreams of encountering extra-terrestrial life might have been a hopeful delusion? Perhaps there will be an answer in the coming century. Until then the great mysteries of finding extraterrestrial life will have to exist in theory - or simply in our popular imaginations. And if one were to ask the native peoples that encountered the great European explorers in previous centuries-that might not be altogether bad. 


\section{Conclusion}

Science fiction author Isaac Asimov said the Moon landing, for all its technological achievement, would likely yield an unexpected result. "It will teach us to be humble. The Earth is a small body, a tiny thing lost in a vast universe."

The early stories of space ships exploring the distant galaxies clearly underestimated the vastness of that universe. It is possible that the realities of space could not sustain the popular curiosity that surrounded the popular imagination of the early $20^{\text {th }}$ century. To this day there are no moon bases - and no domed colonies on Mars. At the same time there were amazing successes. In the 1950s, most estimates predicted the moon would not be reached until the year 2000. That goal was met ahead of schedule - due to the ideological competition between two great scientific powers and the genius of men like von Braun and his Soviet counterpart Sergei Korolev. The reality was that the astronauts could go to the moon by 1970 - but the popular ideas of vacationing on the moon was not realistic. The failure to follow up on the moon landing created a widespread view that the mission had failed to live up to the grand expectations.

Von Braun suggested an analogy could be found in another dramatic "race" earlier that century. In the summer of 1911-12, two rival teams were engaged in a frantic effort to be the first to reach the South Pole. They used only the primitive equipment of snowshoes and dog sleds to reach their destination. But reaching the target was only the first step. It took another 50 years to sustain actual settlements to the South Pole. A similar situation was likely to occur with the Moon. But that required patience and a sustained effort to achieve the desired goal (Clarke).

So was there a point in "going to the Moon and doing the other things"? Over time the "other things" might prove to be as significant as walking on the surface of the moon. The technology of the $21^{\text {st }}$ century has benefitted from several spin off technologies that at one time were only the visionary dreams of a science fiction author - these would include satellite communications, computer technology, advancements in biology and medicine, lighter weight plastics and metal alloys, advances in medicine and surgical techniques, and advances in solar energy collectors - and improving sewage treatment and longer lasting batteries for the modern mobile telephone - that in the 1960s would seem like a device taken directly from an episode of Star Trek.

These achievements were gradual and lacked the glamour of colonizing Mars or encountering "little green men" deep into space. Perhaps one day the "space race" will seem almost quaint - the first small step in a much larger journey. And decades of modern space research has created as many new questions as answers. That includes many of the same some questions that have been pondered since human first began to gaze into the night sky. How big is the universe - and are we alone in it? Time and the scope of history might eventually provide us with answers to that question. But there is also the possibility that we may never know for sure. That verdict, at least for now, remains an open question that continues to inspire the best imaginations on our own planet. And perhaps that is how it should remain. 


\section{References:}

"A Bold Look at the Next Fifty Years of Flight." The New York Times, October 11, 1953.

Address at Rice University, Houston, Texas, 12 September 1962. https://www.jfklibrary. org/Asset-Viewer/Archives/JFKPOF-040-001.aspx, August 1, 2017.

Biddle, Wayne. Dark Side of the Moon: Wernher von Braun, the Third Reich, and the Space Race. New York: W.W. Norton \& Company, 2012.

Bignami, Giovanni, and Sommariva, Andrea. The Future of Human Space Exploration. Westport and London: Palgrave Macmillan, 2004, https://doi.org/10.1057/978-1-137-52658-8.

Buckley, Tom. "NASA's Thomas Paune: Is This a Job for a Prudent Man?" The New York Times, June 8, 1969: 100.

"Cathedrals in the Sky." Time, August 1, 1969. http://content.time.com/time/subscriber/ article/0,33009,901166,00.html, August 1, 2017.

Chertok, Boris. Rockets and People. Vol. 3: Hot Days of the Cold War. Washington: NASA, 2009.

Clark, Avery. "Von Braun and Pickering Warn of Space Setback on 10th Anniversary of First U.S. Shot." The New York Times, February 1, 1968: 6.

Clarke, Arthur C. “The Best is Yet to Come." Time, July 16, 1979. http://content.time.com/ time/magazine/article/0,9171,920504,00.html, August 1, 2017.

D’Antonio, Michael. Wyścig na orbitę. Transl. Marek Krośniak. Warszawa: Prószyński i S-ka, 2012.

Dickson, Paul. Sputnik: The Shock of the Century. London: Bloomsbury, 2009.

Godwin, Robert. Historia podboju kosmosu. Vol. 6: Space Shuttle. Transl. Adrian Markowski. Warszawa: Prószyński Media, 2012.

Golden, Frederic. “Will We Meet E.T.?” Time, April 10, 2000. http://content.time.com/time/ magazine/article/0,9171,996602,00.html, August 1, 2017.

Heppenheimer, Thomas A. Podbój kosmosu: historia programów kosmicznych. Transl. Krzysztof Bednarek. Warszawa: Amber, 1997.

Hodgson, Godfrey. America in Our Time: From World War II to Nixon What Happened and Why. New York: Vintage Books, 1976.

Hoffmann, Paul. “Reds Held Glum Over Moon Feat.” The New York Times, July 28, 1969: 1.

Koppel, Lily. Żony astronautów. Transl. Maciej Prusator. Kraków: Znak, 2014.

Kranz, Gene. Porażka nie wchodzi w grę. Transl. Mariusz Seweryński, and Urszula Seweryńska. Warszawa: Prószyński \& S-ka, 2010.

Kuś, Rafał. PBS. Amerykańska telewizja publiczna, Kraków: Wydawnictwo UJ, 2013.

Lyons, Richard D. "50,000 NASA Jobs To Be Eliminated." The New York Times, January 14, 1970: 1.

McDonald, Alexander. The Long Space Age: The Economic Origin of Space Exploration from Colonial America to the Cold War. New Haven and London: Yale University Press, 2017.

McDougall, Walter A. The Heavens and the Earth: A Political History of the Space Age. Baltimore: Johns Hopkins University Press, 1997.

McQuail, Denis. Teoria komunikowania masowego. Transl. Marta Bucholc, and Alina Szulżycka. Warszawa: Wydawnictwo Naukowe PWN, 2007.

Murray, Charles, and Cox, Catherine Bly. Apollo. The Race to the Moon, New York: Simon \& Schuster, 2004.

"Nazis Planned Rocket to Hit U.S." New York Times, December 4, 1946: 34.

"One Small Ball in the Air: October 4, 1957-November 3, 1957." NASA's Origins and the Dawn of the Space Age. https:/ / www.hq.nasa.gov/office/pao/History/monograph10/ onesmlbl.html, August 1, 2017.

Sagan, Carl. Cosmos, New York: Ballantine Books, 2011.

Schmeck, Harold M. "Von Braun Will Leave NASA for Job in Aerospace Industry." The New York Times, May 27, 1972: 1, 43. 
"Scientist Projects Journey to Mars." The New York Times, September 7, 1951: 30.

"Several Chunks Are Found." The New York Times, July 13, 1979: 7.

Special Message to the Congress on Urgent National Needs. https://www.jfklibrary.org/ Asset-Viewer/Archives/JFKPOF-034-030.aspx, August 1, 2017.

Sullivan, Walter. "Mariner 4's Final Photos Depict a Moonlike Mars." The New York Times, July 30, 1965: 1.

“The Future of NASA." Time, August 10, 1970. http://content.time.com/time/subscriber/ article/0,33009,876752,00.html, August 1, 2017.

“The Moon and Middle America." Time, August 1, 1969, http://content.time.com/time/subscriber/article/0,33009,901158,00.html, August 1, 2017.

“The Scene at the Cape: Prometheus and a Carnival." Time, July 25, 1969, http:/ / content.time. com/time/subscriber/article/0,33009,901103,00.html, August 1, 2017.

"Von Braun Looks to Mars Landing." The New York Times, June 8, 1969.

Whitfield, Steve. Historia podboju kosmosu. Vol. 9: Deep Space. Transl. Adrian Markowski. Warszawa: Prószyński Media, 2012.

“Why Should Man Go To the Moon?" Time. February 10, 1967.

Wilford, John Noble, “\$24-Billion for Big Push to the Moon." The New York Times, July 17, 1969: 34.

Wilford, John Noble. "Moon Landing? What Moon Landing?" The New York Times, December 18, 1969: 30.

Wilford, John Noble. "NASA Layoffs Hit von Braun Team." The New York Times, September 3, 1970: 1, 22.

Wilford, John Noble. "Venus is Found to Be a 'Hellhole.' Where Weird Optical Illusions Abound". The New York Times, October 24, 1967: 17.

Wilford, John Noble. "Wernher von Braun, Rocket Pioneer, Dies" The New York Times, June 18, 1977: 1, 19.

Wolfe, Tom. "One Giant Leap to Nowhere." The New York Times, July 18, 2009. http:/ / www. nytimes.com/2009/07/19/opinion/19wolfe.html, August 1, 2017. 